\title{
Drūmie Staļina represiju gadi Latvijas Universitātē
}

\author{
Aina Dālmane
}

\section{levads}

Tas bija laiks starp pirmo un otro padomju varas okupācijas periodu Latvijā un vācu režīmu starp tiem. Pēc kara beigām Stạlins gribēja pārspēt ārvalstu zinātnes sasniegumus. To solijjās izdarīt T. Lisenko ar saviem paligiem (O. L,epešinsku un G. Bošjanu). Šajos drūmajos laikos 1948. gadā ar likumu bija aizliegta klasiskā genētika, bet šūnām "vajadzēja" veidoties no dzīvās vielas. Politiskās represijas vērsās pret tiem darbiniekiem, kuru radi bija leǵionāri vai arī citādi "kaitīgi" cilvēki. LU fakultātēs daudzi darbinieki gan zinātniskās pārliecỉbas, gan politisko iemeslu dēḷ tika represēti. Visu šo cilvēku mūža gājums ir izziṇas vērts. Šajā rakstā minēšu divus latviešu genētiķus ar pasaules vārdu, kuri tika represēti savas zinātniskās pārliecības dẹḷ. Tie ir Jānis Hilārijs Lielmanis (1895-1970) un Jānis Lūsis (1897-1979).

Jānis Lielmanis 1923. gadā nodibināja Latvijā pirmo selekcijas staciju, bet 1944./45. gadā - pirmo Selekcijas un genētikas katedru, ko likvidēja 1948. gadā. Prof. J. Āboliņš (1906-1990) par viņu ir teicis, ka Jānim Lielmanim Latvijas selekcijā ir tāda pati nozīme, kā Rūdolfam Blaumanim literatūrā.

Jānis Lūsis 1948. gadā, pēc tam kad bija zaudējis darbu Maskavā, jaunu mājvietu atrada LU Biolog̣ijas fakultātes katedrā. Viṇš strādāja daudz, bet génētikā klusēja. Pēc Staļina nāves 1953. gadā pseidozinātne pakāpeniski izzuda, tādēḷ 1966. gadā J. Lūsis katedru pārveidoja par G̦enētikas un zooloǵijas katedru. Interesantas sakritības pēc abi izcilie genētiḳi bija dzimuši Ziemel̦vidzemē.

Arī profesore Veronika Rozenbaha (1916-2003) cieta politisko represiju dēḷ. Neraugoties uz čekas spiedienu, viṇa neatteicās no sava vīra - bijušā leǵionāra. Viṇa bija izcila ārste onkologee, pedagoǵe un zinātniece. 1969. gadā viņa aizstāvēja medicinas zinātṇu doktora disertāciju, bet vajadzēja vēl 11 gadus, lai viṇa iegūtu profesores diplomu. 
Atšķirīga bija LU Medicīnas fakultātes (vēlāk RMI) docētāju attieksme pret genētikas noliegumu. Piemēram, prof. Pēteris Gērke (1904-1985) savā publicēto darbu sarakstā neiekḷāva 1933. gadā Vācijas zinātniskajā presē publicēto rakstu, kas bija pretrunā ar O. L̇epešinskas uzskatiem. Citādi rīkojās prof. Konstantins Bogojavḷlenskis (1899-1967), kurš pret "šķietamo zinātni" mēgināja cīnīties ar neapstrīdamiem faktiem. Viņš piekrita Rỉgas Medicīnas institūta partijas komitejas ieteikumam, lai savai aspirantei Ainai Dālmanei disertācijas darba tēmu izvēlētos no L̦epešinskas tēmu loka. Tomēr disertācijas tēmu viņš nosauca atbilstoši pasaules zinātnes prasībām - "Dzeltenuma veidošanās morfolog̣ija un histoḳimija vistas ovocītos". Šajā darbā Aina Dālmane pierādīja, ka dzeltenumā DNS nav. Tā bez vārdiem bija saprotams, ka šūnas no dzeltenuma lodītēm nevar rasties.

\section{PSRS ZA 1948. gada augusta sesijas reakcionārā ietekme uz Latvijas zinātnes attīstību}

20. gs. vidū (it īpaši no 1945. līdz 1955. gadam) J. Staļina personības kulta laikā valdīja reakcionāra attieksme pret biologijas zinātnēm. Tās kulminācija bija 1948. gada Vissavienības L,enina Lauksaimniecības ZA sesija no 31. jūlija līdz 7. augustam, kurā galvenais bija T. Lisenko (1898-1976) referāts par stāvokli biolog̣ijas zinātnē. Tas bija uzbrukums klasiskajai ǵenētikai, vārdi "veismanisti", "mendelisti", "morganisti" kḷuva par lamuvārdiem. Pēc šìs t. s. augusta sesijas visā bij. PSRS daudzi zinātnieki zaudēja darbu. Skolās un augstskolās vairs nemācīja genētiku, kas ar likumu bija aizliegta. No jauna tā atdzima 20. gs. 60. gados. T. Lisenko, O. L,epešinska un G. Bošjans bija galvenie jaunās padomju ğenētikas radītāji, kuru vadošā literatūra bija "Komunistiskās partijas isais kurss" [1], J. Stalina runas [2] un F. Engelsa "Dabas dialektika"[3]. O. Lepešinskas darba joma bija citologija, embriolog̣ija un histologija, G. Bošjana [4] - mikrobiologija, bet T. Lisenko - lauksaimnieciba.

Pēc J. Stalıina nāves 1953. gadā šĩ viltus biologija pakāpeniski izzuda un atdzima klasiskā genētika, palēnām izlīdzinājās Padomju Savienības biolog̣isko zinātņu atpalicība no pasaules zinātnes.

Olgas L̦epešinskas (1871-1963) galvenais darbības lauks bija revolucionārā cinna, kurā viņa iesaistījās jau 1894. gadā, mācoties Pēterpilī feldšeru kursos, kurus viņa beidz 1897. gadā. No 1897. līdz 1900. gadam viṇa kopā ar vīru atrodas izsūtỉjumā Sibīiijā. Viṇa bija pazisstama ar V. L̦eņinu, par ko raksta grāmatā "Tikšanās ar Iḷjiču" [5]. 1902. gadā O. L̦epešinska sāk studēt medicīnu Šveicē, bet jau 1903. gadā viņa studijas pārtrauc un atgriežas Krievijā, kur darbojas revolucionārajā kustībā. Tomēr pēc laika viņa medicīnas studijas atsāk, un 1915. gadā, 44 gadu vecumā, iegūst ārstes diplomu. Vienu gadu viņa ir asistente Maskavas Universitātes Medicīnas fakultātes Terapijas katedrā, bet revolucionārās darbības dēl vinuu no darba atlaiž. 1919. gadā O. Ĺepešinska ir asistente Taškentas Medicīnas institūta Histolog̣ijas katedrā, no 1920. līdz 1926. gadam - Maskavas 1. Medicīnas institūta Histolog̣ijas katedrā. 1926. gadā O. L̦epešinska ir Timirjazeva 
ZA Biolog̣ijas laboratorijas vadītāja, ko 1949. gadā pārveido par Dzīvās vielas attīstības laboratoriju. Interese par dzīvo vielu viņai radās vēl 20. gadu beigās. 18. gs. beigās un 19. gs. strauji attīstijās audu un šūnu mikropasaules pētījumi. Pētnieki toreiz vēl nemācēja izgatavot plānus un caurspìdīgus mikropreparātus, to pagatavošanas tehnika bija nepilnīga, tādēḷ l̦oti daudzi pētījumi bija kḷūdaini. Tomēr pārsvarā pasaules pētījumi bija progresīvi. Te jāmin F. Fontāna (17321805), kas teica, ka mikroskopā var skatīties ikviens, bet redzēto ne visi sapratīs. Viṇas grāmatā ir vesela nodaḷa par iespējamām interpretācijas kḷūdām [6]. Kaut gan R. Virhova (1821-1902) šūnu teorija "omnis cellulae et cellulae" ir zināma kopš 1858. gada, 19. gs. otrajā pusē un 20. gs sākumā parādijjās pētījumi par šūnu rašanos no dzīvās vielas, piemēram, šādus uzskatus savā runā Kara medicīnas akadēmijas svinīgajā aktā 1900. gada 18. decembrī pauda M. Lavdovskis [7]. M. Lavdovska darba rezultātus pārbaudīja citi zinātnieki un pierādīja, ka tie ir kḷūdaini. 20. gs. pirmajā pusē O. L̇epešinska vēèjās radīt īpašu padomju zinātni, kas būtu pretēja "reakcionārajai" buržuāziskās pasaules zinātnei. Atbilstoši padomju ideolog̣ijai par pētāmo objektu viṇa izvēlējās dzīvo vielu. O. L̦epešinskas zinātniskā pieredze nebija vispusīga, viṇa nebija pētījusi un analizējusi vēsturiskā aspektā problēmu par šūnu rašanos no dzīvās vielas. Nebija brīnums, ka pagājušā gadsimta 30. un 40. gados O. L̇epešinskas zinātniskos rakstus neiespieda un viṇas iesniegtās tēmas konferencēs nepieņēma. Tādẹl viṇa rakstīja J. Staḷinam vēstuli [8], apsūdzot citus zinātniekus par nepatiesiem uzbrukumiem vinai, kas sevi uzskatīja par "īstenās" padomju zinātnes celmlauzi. Tā 79 gadu vecumā sākās O. L̦epešinskas "ziedu" laiki. 1950. gadā viņa kḷuva par PSRS ZA īsteno locekli un Staļina prēmijas laureāti. Viṇas sludinātā pseidomācība nodarīja daudz ḷauna zinātnei. Daudzi jauni, vēl nepieredzējuši zinātnieki šai maldu zinātnei piekrita nepietiekamu zināšanu dēl, citi baidījās par savu likteni un paḳ̣āvās šai tematikai, lai nezaudētu darbu. Piemēram, vadošais patologs J. Davidovskis 1951. gadā [9] "samierinājās" ar to, ka nekrotiskos perēkḷos no sabrukušajām šūnām un audiem, t. i., no nekrotiskās bezšūnu dzīvās vielas rodas šūnas [10]. Iespējams, ka O. L̦epešinskas revolucionārā darbība vai arī tas, ka viṇas zinātniskā darbība "uzplauka" l̦oti cienijjamā vecumā, kḷuva par iemeslu viņas nezinātniskām teorijām. Varbūt tā bija varaskāre (atcerēsimies viṇas vēstuli J. Staḷinam), varbūt tiešām vēlēšanās radīt īpašu padomju zinātni, kas pārspētu visu ārvalstu zinātni. Arī skolu un augstskolu izglîtības sistēmai O. L̦epešinskas pseidomācība nodarīja daudz l̦auna. Tas pats sakāms par viṇas ietekmi uz zinātnisko institūtu un akadēmiju darbu. Jāpiemin, ka 20. gs. vidū O. L̦epešinska divas reizes bijusi Rīgā un referējusi Latvijas Universitātē un Politiskās izglìīibas namā.

\section{Jānis Lielmanis}

Arī Latvijas skolās, augstskolās un Zinātṇu akadēmijā klasiskā genētika bija aizliegta. Jaunās padomju zinātnes uzbrukums skāra Latviju vēl pirms 1948. gada t. s. augusta sesijas Maskavā un "slavenā" T. Lisenko referāta. Viens no pirmajiem, 
kas cieta no padomju režìma zinātniskās pārliecības dēl, bija Jānis Lielmanis - agronoms, selekcionārs un ǵenētiķis. Viņš bija dzimis Ziemel̦vidzemē netālu no Trikātas kā vecākais dēls piecu bērnu goimenē. Viṇa vecāki katram bērnam darbus ierādīja tā, lai visu roku veikums sakḷautos vienotā ritmā. Lasītprasmi viṇam iemācīja mātesmāsa Marija Kepīte. Skolas gaitas Jānis uzsāka 10 gadu vecumā Trikātas Tiepeles skolā. Toreiz draudzes skolā visi priekšmeti, izṇemot mātes valodu un ticības mācību, bija jāmācās krievu valodā. Pēc draudzes skolas beigšanas J. Lielmanis 1909. gadā iestājās Rīgas pilsētas reālskolas otrajā klasē. Šeit viṇš mācījās vienā klasē ar nākamo kinorežisoru S. Eizenšteinu, kura skaistie vēstures tēmu zīmējumi vinuu pārsteidza. Šajā klasē mācī-

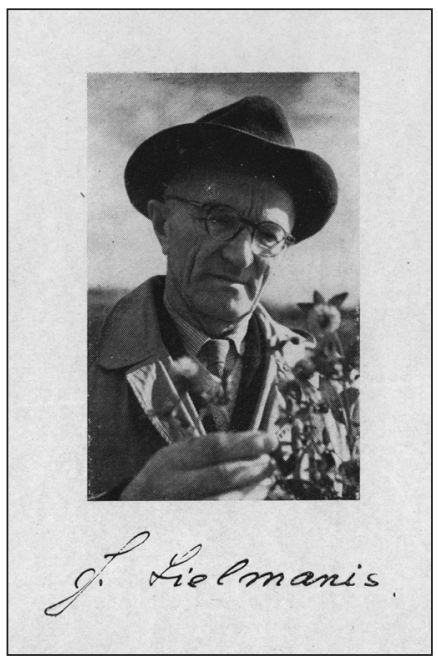
jās arī nākamais agronoms E. Bērziņš, ar kuru J. Lielmanim vēlāk bija kopīgas darba gaitas. Reālskolu viņš beidza ar labām sekmēm 1915. gadā. Māte vēlējās, lai viṇas dēls kḷūtu par mācītāju. Tomēr tēva māju sakārtotu darbu iespaidā viņš nolēma studēt lauksaimniecību un 1915. gadā iestājās Rìgas Politehniskā institūta Agronomijas fakultātē. Sākoties Pirmajam pasaules karam, Politehnisko institūtu evakuēja uz Maskavu. Lai turpinātu studijas, uz Maskavu devās arī J. Lielmanis, kur viņš no 1915. līdz 1920. gadam mācības turpināja Maskavas Lauksaimniecības institūta Agronomijas fakultātes neklātienes nodạ̦ā. Šeit viṇš klausījās lekcijas pie ievērojamiem tālaika zinātniekiem (V. Viljamsa, D. Prjaṇišņikova, A. Dorjaņenko).

Lai iegūtu studijām naudu, J. Lielmanis strādā dažādus ar lauksaimniecỉbu saistītus darbus. Nodibinoties padomju varai, vinu nosūta uz laukiem par pārtikas rekvizitoru. Tas bija iemesls, kāpēc J. Lielmanis pārtrauca studijas Maskavā un 1920. gadā pārbēga uz Latviju. Tajā pašā gadā viņš iestājas LU Lauksaimniecỉbas fakultātē, kur viņš atkal ir kopā ar savu draugu un bijušo klasesbiedru E. Bērziņu. 1922. gadā pirms studiju beigšanas J. Lielmanis lauksaimniecības prakses laikā mācijās Dānijā, Ziemeḷzēlandes paraugsaimniecībā Holmeredgārdā, kā arī iepazinās ar Dānijas lauksaimniecības izmēgeinājumu staciju darbu. 1922. gada 12. jūnijā J. Lielmanis ieguva pirmās škiras mācīta agronoma grādu ar visām likumā paredzētām tiesībām. Studiju laikā J. Lielmanis iepazinās ar profesora J. Berga asistenti Annu Pauliṇu (1893-1982) un 1923. gadā kopā ar viṇu uzsāka kopīgu dzīves ceḷu. Anna Lielmane visu mūžu atbalstīja savu vīru. G̣imenē piedzima meitas Rita (tagad Rita Dālmane) un Vija (tagad Vija Silinana). Jānim un Annai Lielmaṇiem bija 5 mazbērni, 2 mazmazbērni un 2 mazmazmazbērni. 


\section{A. Dālmane}

Pirmā pasaules kara laikā Latvijas lauksaimniecība bija stipri cietusi. Bez tam Latvijā tikpat kā nebija selekcionētu škirṇu, kas būtu piemērotas tās apstākḷiem. 1922. gada rudenī Latvijas Zemkopỉbas ministrija uzdeva Jānim Lielmanim organizēt un izveidot Stendes selekcijas staciju Talsu apriņ,̧̧a Stendes muižā. Lai papildinātu zināšanas šajā jomā, 1923. gadā J. Lielmanis kopā ar E. Bērziṇu apmeklēja Vācijas, Zviedrijas un Dānijas selekcijas stacijas.

Zināšanas sēklkopībā un selekcijas darbā J. Lielmanis papildināja, sistemātiski lasot jaunāko ārzemju zinātnisko literatūru. Viņš izveidoja labu bibliotēku Stendes selekcijas stacijā un mudināja zinātniskos līdzstrādniekus sistemātiski sekot visam jaunajam pasaulē, kā arī papildināties svešvalodu apguvē. Lai uzlabotu pētnieciskos darbus, pēc J. Lielmaṇa lūguma 1933. gadā Stendē ierīkoja 2. šķiras meteorolog̣isko staciju, kurā bija instrumenti gaisa spiediena, temperatūras, mitruma, nokrišņu daudzuma, vēja virziena un ātruma, kā arī saules spīdēšanas ilguma noteikšanai. Zinātniskais darbs un selekcija Stendes selekcijas stacijā jau no paša sākuma bija loti apjomīgs (auzu, ziemas kviešu, rudzu, kartupeḷu, zirṇu un āboliṇa selekcija, kā arī linu izkopšana un cukurbiešu izmēǵinājumi).

1933. gada 28. aprīlī J. Lielmanis Augkopības katedrā aizstāv habilitācijas darbu "Pētijjumi par auzu šķirṇu audzēšanu un aklimatizāciju". Šajā pašā gadā viņu ievēl par privātdocentu, un viņš sāk lasìt Lauksaimniecības fakultātes studentiem lekcijas par augu selekciju. 1933. gada 17. novembrī J. Lielmani apbalvoja ar Triju Zvaigžņu ordeṇa 4. pakāpi. 1938. gadā [12] iznāca J. Lielmaṇa grāmatas "Augkopỉba" pirmais izdevums. 1940. gadā Latvijas Universitātes Lauksaimniecības fakultāti pārveidoja par Jelgavas Lauksaimniecības akadēmiju. Tai pašā gadā, nodibinoties padomju varai, J. Lielmanis vairs nav Stendes selekcijas stacijas vadītājs. Lai izvairītos no represijām, J. Lielmaṇa gimene 1940. gada oktobrī pārcēlās uz dzīvi Rīgā. No 1940. līdz 1944. gadam J. Lielmanis bija Lauksaimniecības akadēmijas docents, viņš lasīja lekcijas selekcijā un genenētikā.

Arī Otrā pasaules kara laikā J. Lielmanis nepārtrauca zinātniskos pētỉjumus, kas noritēja Vecauces mācību saimniecībā ar ābolin̦a un graudaugu kultūrām. No 1942. līdz 1944. gada vidum J. Lielmanis vienlaikus darbam Jelgavas Lauksaimniecības akadēmijā bija Lauksaimniecības generāldirekcijas Zemkopības nodalıas vadītājs. 1944. gadā A. Punkas apgādā iznāca J. Lielmaņa grāmatas "Augkopība" otrais izdevums [13]. Otrā pasaules kara beigu posmā, pateicoties J. Lielmaņa dzīvesbiedres ietekmei, viņa gimene no Latvijas neaizbrauca, bet 1944. gada rudenī devās bēgḷu gaitās uz Kurzemi, uz Stendi. 1945. gada pavasarī J. Lielmanis pēc Stendes selekcijas stacijas darbinieku lūguma palīdz veikt sējas darbus. Drīz pēc Vācijas kapitulācijas Stendē ieradās toreizējais zemkopības ministrs J. Vanags, lai organizētu pavasara sēju. Ministrs bija pārsteigts, kad J. Lielmanis viṇam parādīja sadīgušos labību sējumus un iestādītos kartupeḷu laukus. Tà J. Lielmani ar 1945. gada 9. maiju iecēla par Stendes selekcijas stacijas direktora vietas izpildītāju. Tomēr par selekcijas stacijas vadītāju J. Lielmani neatstāja, un no 1946. gada janvāra līdz 1947. gada decembrim viņš bija Stendes selekcijas 
stacijas direktora vietnieks zinātniskajā darbā. 1945. gadā J. Lielmanis turpināja darbu Lauksaimniecības akadēmijā, vadot Selekcijas un genētikas katedru. Tajā pašā gadā iznāca arī viņa grāmatas 3. izdevums [14]. 1947. gadā viṇu ievēlēja par Selekcijas un sēklkopỉbas katedras docentu. Staḷina personības kulta laikā J. Lielmanis 1947.-1948. gadā sava zinātniskā un pedagog̣iskā darba dēḷ saṇēma smagu 'kritiku". Pret J. Lielmani vērsās Latvijas PSR ZA korespondētājloceklis J. Bumbieris, kas viṇu nosauca par buržuāzisko nacionālistu [15]. Negatīvā preses attieksme pret J. Lielmani nevēlami ietekmēja viņa darbu Stendē, un 1947. gada decembrī viṇu no direktora zinātniskā vietnieka pazemina par stacijas Selekcijas nodaļas un zālāju grupas vadītāju. Negatīvās pārmaiņas J. Lielmaṇa dzīvē turpinājās arī 1948. gadā pēc T. Lisenko ziņojuma "Par stāvokli bioloǵijas zinātnē", kad pie mendelistiem-morganistiem pieskaitīja ne vien Lielmani, bet arī augsnes apstrādes pētnieku prof. J. Apsīti, biškopības un putnkopības speciālistu P. Rizgu un citus. Viṇu uzskatus nosodija Latvijas PSR ZA pilnsapulces rezolūcijā "Par Vissavienības V. I. L̦eṇina vārdā nosauktās Lauksaimniecības zinātṇu akadēmijas sesijas rezultātiem jautājumā par stāvokli biologiijas zinātnē". Tajā teikts, ka Latvijas PSR ZA nosoda Stendes selekcijas stacijas zinātniskā darbinieka J. Lielmaṇa pseidozinātniskos rakstus viṇa grāmatā "Augkopība". Tomēr J. Lielmanis nemainīja savus uzskatus selekcijā un palika klasiskās genētikas piekritējs [16]. Tāpēc 1948. gadā viṇu atbrīvoja no darba Latvijas Lauksaimniecỉbas akadēmijā $[17,18,19]$. Tomēr J. Lielmanis turpināja sarkanā āboliṇa šḳirṇu izpēti līdz pat 1955. gadam.

Ilggadēja darba rezultātus J. Lielmanis apkopoja 1956. gadā savā kandidāta disertācijā "Vēlīnā sarkanā āboliņa šķirnes "Stendes vēlais II" izaudzēšana. Atgādinājumam jāpiemin, ka J. Lielmaņa 1933. gadā iegūto habilitētā doktora grādu padomju vara neatzina, tāpēc vinšs 1957. gada martā Latvijas Lauksaimniecỉbas akadēmijā aizstāvēja kandidāta disertāciju. Ar 1956. gada novembri J. Lielmanis izbeidza savu darbību Stendes selekcijas stacijā, kur ar pārtraukumiem bija strādājis no 1922. lìdz 1956. gadam.

Pēc J. Staḷina nāves 1953. gadā, pakāpeniski apsīkstot T. Lisenko pseidozinātnei, Latvijā pārveidojās ZA institūcijas, un 1956. gadā nodibināja Latvijas Zemkopības zinātniskās pētniecỉbas institūtu, iekḷaujot to Latvijas PSR Lauksaimniecības ministrijas zinātniskās pētniecības iestāžu sistēmā. 1959. gadā šo institūtu pārvietoja uz Aizkraukles (toreiz Stučkas) rajona Skrīveru ciematu. 1956. gadā J. Lielmani no Stendes selekcijas stacijas pārcēla darbā uz Latvijas Zemkopības zinātniskās pētniecỉbas institūtu par Augkopības sektora vadītāja vietas izpildītāju, ievēlot tā paša gada decembrī par jaunizveidotās Augkopības nodaļas vadìtāju. J. Lielmanis tajā bija trešais zinātniskā darba vadītājs, visi zinātniskie darbinieki (F. Jansons - 1961, O. Sīviņš - 1965, A. Lācis - 1968, A. Antonijs - 1970, E. Krēsliṇš - 1968) aizstāvēja kandidāta disertāciju. 1957. gadā Latvijas PSR Augstākā Padome J. Lielmanim piešḳīra Nopelniem bagātā agronoma goda nosaukumu, bet 1959. gadā Latvijas PSR Ministru Padome viṇam pieškīira Latvijas PSR Valsts prēmiju. 


\section{A. Dālmane}

Vēlāk pret J. Lielmaņa iemịloto sarkano āboliṇu vērsās N̦. Hruščovs, kritizējot zemkopības zālaugu sistēmu. Pret āboliņa audzēšanu spiediens nāca gan no Maskavas, gan Latvijas PSR Lauksaimniecibas ministrijas. Kā atceras J. Lielmaņa darbinieks F. Jansons, toreiz bija jāsēj trīs "valzivis": cukurbietes, kukurūza un lopbarības pupas. Tomēr pēc dažiem gadiem ābolinšs no jauna atguva savu vietu lauksaimniecībā. 1965. gadā J. Lielmanim pieškīra Latvijas PSR Nopelniem bagātā zinātnes darbinieka nosaukumu. 1968. gada 31. maijā J. Lielmanis Latvijas Lauksaimniecības akadēmijā aizstāvēja lauksaimniecības zinātṇu doktora disertāciju "Sarkanais āboliņš un tā audzēšana Latvijas PSR". PSRS Augstākā atestācijas komisija J. Lielmaņa doktora grādu apstiprināja 1969. gadā. Tā pēc 36 gadiem J. Lielmanis atguva zinātnisko grādu, kas viņam bija pieškirts jau 1933. gadā. Lielās zinātniskās darba slodzes dēl pasliktinājās J. Lielmaṇa veselība, tādēl J. Lielmanis pēc paša lūguma kḷuva par Selekcijas nodaļas vecāko zinātnisko līdzstrādnieku. Aizsaulē J. Lielmanis aizgāja 1970. gada 4. martā, viṇu apbedīja Rīgā, Lāčupes kapos. Jānis Lielmanis bija cilvēks ar patiesu zemnieka dvēseli, zinātnieks, ko nevarēja salauzt un kas sabiedrības intereses turēja augstāk par visu.

1991. gadā par izciliem sasniegumiem kultūraugu selekcijā un augkopībā tika nodibināta Jāṇa Lielmaṇa prēmija.

\section{Jānis Lūsis}

Jānis Lūsis bija Latvijā pirmais genētiḳis, biologs un zoologs ar pasaules vārdu. Viņš piedzima 1897. gadā Valmieras apriṇka K̦oṇu ciema "Kalniņos" zemnieku

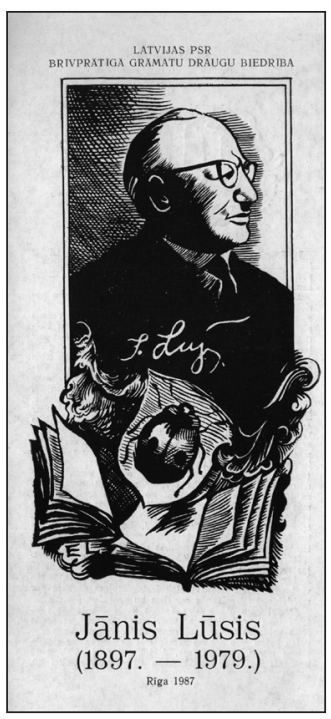
gimenē. Jānis bija vecākais bērns. Vēl viņam bija divas māsas - Milda un Olga - un brālis Arvīds.

Arvīds Lūsis (1900-1969) bija pirmais matemātik̦is, kas izglīîibu ieguva LU Matemātikas un dabaszinātṇu fakultātes Matemātikas nodạ̦ā. Vienlaikus ar studijām viņš 1921 . gadā beidza Izglīiības ministrijas vidusskolu Skolotāju sagatavošanas kursus matemātikā. Visu mūžu strādājis LU, ilgus gadus būdams vienīgais profesors Fizikas un matemātikas fakultātē. Pateicoties viñam, pēckara gados Fizikas un matemātikas fakultātē saglabājās augsts pedagoǵiskais un zinātniskais līmenis, veidojās spējīgi matemātiḳi. 1969. gadā A. Lūsim piešķirts Nopelniem bagātā zinātnes darbinieka nosaukums [20,21].

Pirmo izglìtîbu Jānis Lūsis iegūst Ķoṇu trīsgadīgajā skolā (1906-1909), tad mācās Rūjienas draudzes skolā (1909-1912) un Valkas reālskolā (1912-1916). 1916. gadā izglìīibu turpina Petrogradas universitātes Fizikas un matemātikas fakultātes Biolog̣ijas nodậā. Studiju gados J. Lūsi ietekmē izcili universitātes 
zinātnieki (I. Fiḷipčenko, brāḷi A. un V. Dogel̦i, V. Komarovs u. c.). Studiju laikā J. Lūsis veic pirmos pètījumus par laputu mainību, par mārǐšu polimorfismu un genētiku u. c. Tāpat studiju gados (1921) viņš sāk strādāt par zinātnisko līdzstrādnieku Krievijas Ražošanas spēku komisijas cilvēka iedzimtības pētī̌anas birojā. 1923. gadā viņš beidz universitāti un paliek darbā G̣enētikas un zoologijas katedrā. No 1929. līdz 1932. gadam viňš ir Vissavienības lopkopības institūta Cūku selekcijas sektora vadītājs, no 1930. līdz 1940. gadam vada PSRS G̣enētikas institūta Mājlopu genētikas, selekcijas un evolūcijas nodaḷu, no 1941. līdz 1942. gadam strādā PSRS Zinātṇu akadēmijas Zoolog̣ijas institūtā, bet no 1942. līdz 1948. gadam A. Severceva Evolucionārās morfologiijas institūtā. Vienlaikus viṇš sistemātiski veic pedagoǵisko darbu; 1935. gadā viņam pieškị profesora nosaukumu.

20. gs. 20. gadu otrajā pusē J. Lūsis sāk pētīt Vidusāzijas mājdzīvniekus. 1933. gadā viņš uzsāk genētiskus pētijumus, krustojot Kirgīiijā arharus ar kurdjukaitām. 1937. gadā viņš vada darbu par āžu un mājas kazu krustošanu. 20. gs. 30. gadu vidū J. Lūša vadībā sākās jaunas aitu škirnes izveidošana Kazahijas un Kirgīzijas augstkalnu rajonos, krustojot savval̦as aitas (arharus) ar kurdjukaitu un smalkvilnas škikirnes merīnaitām. Darbs tika pabeigts 1950. gadā, aprobējot PSRS jauno arharu merīnaitu škirni, bet, kad darba veicējiem piešḳīa Stalıina prēmiju, J. Lūša autoru sarakstā vairs nebija. Jau 1937. gadā sākās Staḷina režīma terors pret mazākumtautībām, arī latviešiem. Šajā laikā sākās arī T. Lisenko un viṇa piekritēju uzbrukums klasiskajai ǵenētikai. No represijām neglāba nedz zinātniskie nosaukumi, nedz arī nopelni un sasniegumi zinātnē. T. Lisenko pseidozinātnieku grupa ar Staļina atbalstu panāca pat izcilu zinātnieku fizisku iznīcināšanu. Piemēram, 1940. gadā arestēja krievu genenētikị un selekcionāru N. Vavilovu, kurš 1943. gadā nomira Saratovas cietumā. J. Lūsis dzīvỉbu nezaudēja, bet 1948. gadā pēc t. s. PSRS Lauksaimniecības Zinātṇu Akadēmijas sesijas palika bez darba, jo viṇš joprojām atzina ǵenētikas pamattēzes par pareizām.

Ar LVU rektora Matveja Kadeka (1897-1950) pavēli J. Lūsis sāk strādāt par profesoru LVU bez tiesībām paust ǵenētikas atziṇas. Sākās Jāṇa Lūša jaunā dzīve Rīgā Biologiijas fakultātes Cilvēka un dzīvnieku fiziologiijas katedrā [22, 23]. Šis J. Lūša dzīves laiks ilgst 30 gadus (1949-1979). Tomēr arī Rìgā J. Lūsim nācās uzklausīt Lisenko kliķes pārmetumus par nepietiekamu I. Mičurina un T. Lisenko cildinājumu [24]. Nevienā J. Lūša zinātniskajā plānā nebija mārǐšu pētījumu, toties sākās cukurbiešu kaitēkḷu entomofaunas pètījumi, kā arī Latvijas karpu un to hibrīdu pētījumi ar Amūras sazāniem. J. Lūsis lasīja lekcijas, vadīja studentu kursadarbus un diplomdarbus, strādāja ar aspirantiem, brauca ar studentiem praksē un ekspedīcijās ne tikai Latvijā, bet arī viṇa tik mịlajā Vidusāzijā. 1951. gadā Jānis Lūsis kḷuva par Biologijas fakultātes Zoolog̣ijas katedras vadītāju, bet 1958. gadā viṇu ievēlēja par LPSR ZA korespondētājlocekli. 1959.-1960. gadā viņš ir ZA Ihtioloǵijas sektora vadītājs, bet 1961. gadā izveido Bioloǵijas fakultātē Zooloǵijas muzeju. J. Lūsis bija viens no autoritatīvākajiem latviskās zoolog̣ijas terminologijas veidotājiem. 
Pēc J. Stalıina nāves 20. gs. 50. gadu otrajā pusē pakāpeniski izzuda T. Lisenko vara un atdzima klasiskā genētika. 1966. gadā Biologijas fakultātes Zooloğijas katedru pārdēvēja par Zoolog̣ijas un genētikas katedru [25]. 1966. gadā nodibināja N. Vavilova Vissavienības G̣enētiķu un selekcionāru biedrību, kuras centrālajā padomē darbojās arī J. Lūsis. 1967. gadā J. Lūsis dibina šās biedrības Latvijas nodalıu, kas tagad ir pārtapusi par G̣enētiḳu un selekcionāru biedrību. 1966. gadā J. Lūsis oficiāli piesaka zinātnisku tēmu par mārīšu genētiku. Kopš šì briža profesors Jānis Lūsis studentiem lasa ne vien zoologiiju, variācijas statistiku un entomoloǵiju, bet arī ǵenētiku. Arī oficiālās valsts iestādes atzina prof. J. Lūša nopelnus un saglabāto zinātnieka godīgumu, 1965. gadā piešķirot viṇam Latvijas PSR Nopelniem bagātā zinātnes darbinieka nosaukumu, bet 1968. gadā viņu apbalvo ar Darba Sarkanā Karoga ordeni. No 1976. gada J. Lūsis Zooloǵijas un genētikas katedrā samazināja darba slodzi un kḷuva par zinātnisko konsultantu [26]. Profesors Jānis Lūsis miris 1979. gada 10. augustā; apbedīts Rīgas Meža kapos.

Sarežgiitais un grūtais abu izcilo latviešu genētiḳu mūžs un darbs mūsdienu enciklopēdijās diemžēl aplūkots pārāk īsi [27].

\section{Veronika Rozenbaha (1916-2003)}

Veronika Rozenbaha (dz. Krūmiņa) dzimusi 1916. gadā Pleskavā. 1920. gadā vecāki ar mazo Veroniku atgriežas Latvijā. Jau piecu gadu vecumā Veronika iemācijāa lasīt un strādāt rokdarbus. 1924. gadā sākās Veronikas skolas gaitas Rīgas 41. pamatskolā, pēc tam 2. Rìgas pilsētas ǵimnāzijā, kuru viņa beidza 1936. gadā.

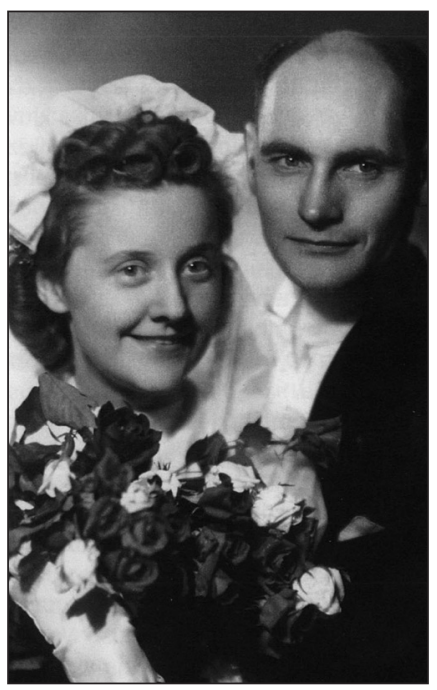
Lai gan Veronikai bija mịli un atbalstoši vecāki, viņa saprata, ka izglītībai jāpelna arī pašai nauda. 1936. gadā viņa beidza A. Liepiṇa mašīnrakstī̌šnas, grāmatvedības un valodu kursus. 1936. gadā vienlaikus ar darbu 1. Rīgas pilsētas slimnīcas kancelejā viņa uzsāka studijas Angḷu valodas institūtā, kurā māca ne vien angḷ sarunvalodu, gramatiku, fonētiku, vēsturisko gramatiku un rakstniecības teoriju, bet arī filozofiju, sistemātisko un moderno psiholoğiju, audzināšanas teoriju un vēsturi. Mācỉbu laikā viņa pievērsās arī zīmēšanai, darinot pati sev grāmatzīmes. 1940. gadā viṇa ar loti labām sekmēm beidza Angḷu valodas institūta pedagoǵijas nodal̦as pilnu kursu [28]. Šajā laikā tēva ilgstošā slimošana modināja viņā interesi par medicīnu, tādēl viņa iestājās LU Medicīnas fakultātē, kur vienlaikus ar mācībām un darbu daudz 
lasīja, vēelēdamās iedziḷināties zinātnē un sagatavoties ārstes darbam. 1945. gadā V. Rozenbaha beidz LU Medicīnas fakultāti.

Vēl studiju laikā 1944. gadā viņa salaulājās ar LU Mehānikas fakultātes studentu virsnieka vietnieku Frici Rozenbahu (1909-1980), kuru 1946. gadā arestē un aizsūta uz Maskavas apgabalu, kur pēc Kriminālkodeksa 58.-1. a panta notiesā ar brīvības atṇemšanu uz desmit gadiem ieslodzījumā un pieciem gadiem bez tiesībām atgriezties. V. Rozenbahai nācās daudz ciest. Dažkārt viṇu aizturēja uz ielas un t. s. "stūra mājā" pratināja vairākas stundas. 1950. gadā viṇai ieteica šḳirties no vīra, tomēr viṇa tam nepiekrita, tādēl bija jāraksta paskaidrojums Republikas klīniskās slimnīcas partijas organizācijai. No katorgas Sibīrijā F. Rozenbahs atgriezās 1955. gadā, bet viṇu reabilitēja tikai 1999. gadā - 19 gadus pēc nāves. Lai gan F. Rozenbahs pēc Stalina nāves tika atbrīvots, represijas pret V. Rozenbahu turpinājās. Tā, piemēram, 60. gados viṇai nel̦āva braukt uz Vācijas Demokrātisko Republiku. V. Rozenbaha prata slēpt savus pārdzivojumus un darbabiedri pat iedomāties nevarēja, kāda ir viņas dzīve, kādi sarežğìjumi viņai ir jāpārdzīvo.

Jau studiju gados, būdama Medicīnas fakultātes subasistente, V. Rozenbaha veica laboratoriskas analīzes, asinsrites sistēmas funkcionālās pārbaudes slimniekiem ar kuṇga vēzi un kungga čūlas slimību. Pēc LU beigšanas 1945. gadā vienlaikus ar ķirurga darbu viṇa sāka strādāt par asistenti LU Fakultātes kịurgijas katedrā profesora P. Stradiņa vadībā un gatavojās zinātniskajam darbam. 1946. gadā viṇa kḷuva par aspiranti onkolog̣ijā. Viṇas pirmā disertācijas tēma par vēža šūnu mitogenētisko starojumu Medicinnas fakultātes partijas komitejai likās nepareiza no ideologiskā viedokḷa. Tādēl, neraugoties uz pozitīviem darba rezultātiem, to lika pārtraukt. Otrā tēma bija "Asins seruma kopīgā olbaltuma un olbaltuma frakciju pārmaiņas vēža slimniekiem atkarībā no terapijas". Zinātnisko literatūru V. Rozenbaha lasīja ang̣̣u, krievu, vācu, franču, latịnu un poḷu valodā. Viṇas disertācijas darba pētijumi bija nepieciešami, lai apgūtu un ieviestu praksē agrīn̄s vēža diagnostiskās metodes. Viņa konstatēja slimnieku asins serumā palielinātu globulīna daudzumu, ko izskaidroja ar vēža intoksikāciju. 1953. gadā viṇa aizstāvēja kandidāta disertāciju. No 1950. līdz 1965. gadam V. Rozenbaha ir RMI Fakultātes k̦irurǵijas katedras asistente, bet no 1965. līdz 1974. gadam viņa ir docente un vada onkolog̣ijas ciklu RMI Ārstu kvalifikācijas celšanas fakultātē. Onkologijas studentu zinātniskā pulciņa dalībniekus viņa centās iesaistīt klīnikas ikdienas darbā. V. Rozenbaha bija Latvijā pirmā, kas izstrādāja un novērtēja komplekso metožu nozīmi krūts vēža diagnostikā [29]. Viņa apvienoja instrumentālo un citoloǵiskās izmeklēšanas metodes rezultātus, kas uzlaboja krūts vēža agrīno diagnostiku. 1969. gadā V. Rozenbaha aizstāvēja medicīnas zinātņu doktora disertāciju "Krūts vēzis - diagnostika un ārstēšana". Neraugoties uz V. Rozenbahas l̦oti intensīvo klīnisko un zinātnisko darbu, apritēja 11 gadi, līdz viṇa 1980. gadā ieguva profesores diplomu. No 1974. lìdz 1995. gadam V. Rozenbaha turpina strādāt RMI Onkolog̣ijas katedrā, bet 1995. gadā aiziet pensijā. Mainijās dzīves ritms, viņa bija atrauta no darba. Dzivesprieku V. Rozenbaha atguva tikai tad, 
kad sākās materiālu kārtošana par polimēro ārstniecisko vielu sintēzi un izmantošanu medicīnā.

Profesore Veronika Rozenbaha godam nostaigāja savu dzīves ceḷu līdz pēdējam mirklim 2003. gada 3. janvārī. Viṇas ticība labajam ḷāva izturēt čekistu pāridarijumus. 80 publicēto darbu saraksts liecina, ka Veronika Rozenbaha bija îstena darba darītāja, lai gan ne vienmēr viṇa ir raksta pirmā autora vietā.

\section{Konstantins Bogojavḷenskis (1899-1967)}

Profesors Bogojavḷenskis atbrauca uz Latviju 1947. gadā un kḷuva par LVU Medicīnas fakultātes Histolog̣ijas katedras vadītāju. Viṇš bija pieredzējis zinātnieks un pedagogs. Pēc Jāṇa Arnolda Egliša un Irmas Liepiñas-Eglìtes emigrēšanas viņš sakārtoja sagrauto histoloǵijas mācību procesu. Vienlaikus viṇš veica nukleīnskābju citoḳīmiskus pētījumus, ḳ̣ūdams par citoloğiskā un citoḳimiskā virziena aizsācēju Latvijā. Viņšr radīja citologu un histologu skolu, viņa vadībā veidojās vietējie kadri (aizstāvētas 4 promocijas un 2 habilitētā doktora disertācijas). Profesors Bogojavḷenskis bija cīnītājs, viṇš pretojās no augšas uzspiestām dogmām. Savas pirmās aspirantes Ainas Dālmanes disertācijas tēmu L̦epešinskas pseidozinātnes garā, kuru ieteica partijas komiteja, viņš gan akceptēja, bet to nedaudz pārveidoja pēc savas gaumes. Viṇa piedāvātā tēma bija "Dzeltenuma veidošanās morfoloğija un histoḳimija vistas ovocìtos". Viņš uzskatīja, ka vispirms jāpētī dzeltenuma lodī̌u rašanās, un tikai pēc tam - iespējamā šūnu rašanās no tām. Dzeltenuma veidošanās procesu ovocìtos var salīdzināt ar sekrēta veidošanos dziedzeršūnās. K. Bogojavl̦enskis vietējos kadrus sagatavoja l̦oti rūpīgi un atbildīgi, uzskatot, ka vienlaikus ar zinātniskiem pētījumiem jāuzkrāj arī zināšanas par citologijas un citokīmijas attīstỉbas gaitu, lai varētu paredzēt mācību procesa attīstību nākotnē. Tāpēc A. Dālmanes pirmais uzdevums bija iepazǐšanās ar zinātnisko žurnālu rakstiem no 19. gs. vidus līdz 20. gs. vidum, kurus aspirante pētīja gan Rīgas, gan Maskavas un citu pilsētu bibliotēkās. Šā darba secinājumi - no šūnu teorijas sākuma līdz 20. gs. vidum ir skaidri redzama zinātnes attīstības līnija. 19. gs. beigās bija jau iepazìta šūnu biolog̣ija, daḷeji arī genētika, sākās citoḳīmiski pētījumi. 20. gs. variēja un saistīja klasiskās, citoḳimiskās un genētiskās pètī̌̌anas metodes. 20. gs. vidū vienlaikus izmantoja dažădas metodes šūnu struktūrām un vielām, kas ar tām saistītas, piemēram, Goldži kompleksam un sekrēta sastāvam. Sākās kvantitatīvas histolog̣isko preparātu analīzes, gaisā jau vēsmoja citologísko struktūru elektronmikroskopiskā analīze. Nozīmīgs bija arī otrais uzdevums - pārbaudīt visas pieejamās histolog̣ijas un citolog̣ijas mācību grāmatas, lai varētu secināt, cik ilgā laikā jaunie zinātnes sasniegumi nonāk un tiek atspoguḷoti mācību grāmatās. Disertācijas darba izstrādāšana tiešām bija atbildīga, tomēr galvenais uzdevums, ņemot vērā RMI iespējas, bija klasisko metožu un histoḳimisko reakciju kombinācijas dzeltenuma veidošanās gaitā. Tika histoḳīmiski pētīti tauki (lipīdi, lipoīdi, holesterīns, lecitīns), aminoskābes (arginīns, triptofans, histidīns, glutations, tirozīns), glikogēns, nukleīnskābes. Šie 
pētījumi bija l̦oti darbietilpīgi, jo dažādās ovocīta dzeltenuma veidošanās stadijās bija jāskaita visu šūnu griezumu sērijas. 20. gs. vidū līdzīga darba par šādu tēmu nebija. Galvenais secinājums, kas bija vērsts pret O. L̦epešinskas kḷūdainajiem uzskatiem, bija šāds: nedz attīstības laikā, nedz jau izveidotajās dzeltenuma lodītēs DNS nav. Tā bez vārdiem tika pateikts, ka šūnas no dzeltenuma lodītēm nevar rasties. Disertācija bija uzrakstīta latviešu valodā, autoreferāts - krievu valodā [30, 31]. Aina Dālmane to aizstāvēja 1955. gadā. Par to bija ḷoti daudz pozitīvu atsauksmju no dažādām PSRS zinātniskām iestādēm.

No Ziemel̦vidzemes ir nākuši divi pirmie latviešu izcilie genētiḳi - agronoms Jānis Hilārijs Lielmanis (1895-1970) un zoologs Jānis Lūsis (1897-1979). Abi cieta Stalina represiju un T. Lisenko viltus biolog̣ijas laikā. J. Lielmanim neatzina jau 1933. gadā iegūto habilitācijas doktora grādu, atṇēma iespējas vadìt selekcijas un genētikas pētījumus, kā arī padzina no mācību darba Latvijas Lauksaimniecības fakultātē. Tomēr J. Lielmanis 1957. gadā aizstāvēja kandidāta disertāciju un 1968. gadā arī doktora disertāciju.

Pēc bēdīgi slavenā T. Lisenko referāta 1948. gada Vissavienības L̦eninina Lauksaimniecības zinātṇu akadēmijas sesijā Maskavā darbu zaudējušais ğenētiḳis ar pasaules vārdu J. Lūsis paglābās Latvijas Universitātes Bioloǵijas fakultātē, mācot zoologiju un klusējot par genētiku. Tikai pēc genētikas oficiālās atzišsanas 20. gs. sešdesmitos gados J. Lūsis atsāka genētiskos pētījumus. Mūsdienu enciklopēdijās informācija par J. Lielmani un J. Lūsi ir tikai dažu teikumu apjomā, kas mums šḳiet nepietiekami. Staļina represijas skāra arī gimenes, kuru locekḷi bija leǵionāri, tātad atradušies 2. Pasaules kara nepareizajā pusē. Tā V. Rozenbahu (Krūminuu) pēckara gados vajāja čeka, liekot pat škirities no vīra leǵionāra. Tomēr arī viṇa savu grūto mūžu vadija cēla un nesalauzta.

Atšķirīga bija LU MF, bet vēlāk RMI docētāju, arī katedru vadītāju attieksme pret ǵenētikas noliegumu. Prof. P. Gērke (1904-1985) savu darbu sarakstā neiekḷāva 1933. gadā vācu žurnālā publicēto darbu par dzeltenuma veidošanos lancetnieka ovocitos, kas bija pretrunā [32] ar O. L̦epešinskas uzskatiem par šūnu rašanos no dzeltenuma lodītēm. Citādi rīkojās K. Bogojavḷenskis (1899-1967), kas uzskatīja, ka pret muḷıỉibu jācīnās ar atbilstošiem, neapstrīdamiem "ieročiem". Tādēl saskaņā ar RMI partijas organizācijas ieteikumu viņš savai aspirantei Ainai Dālmanei ieteica L̦epešinskas tematikai atbilstošu darba tēmu - "Dzeltenuma veidošanās morfolog̣ija un histoḳimija vistas ovocītos". Šajā darbā Dālmane pierādīja, ka dzeltenumā nav DNS. Tā bez liekiem vārdiem bija saprotams, ka no dzeltenuma šūnas nevar rasties.

\section{Vēres}

1. История ВКП(б). Краткий курс. Москва: Госполитиздат, 1950, с. 68, 101.

2. Ответ товарища Сталина на письмо тов. Разина. Больщевик, № 3, 1947, с. 7. 
3. Энгельс Ф. Диалектика природы. Москва: Госполитиздат, 1950, с. 243245.

4. Бошьян М. О природе вирусов и микробов. Москва: Медгиз, 1950, с. 1-147.

5. Лепешинская О. Встречи с Ильичом. Москва: Госиздат. полит. литературы, 1957, с. 1-40.

6. Фонтана Ф. цит. по Е. М. Вермель. История учении о клетке. Москва: Наука, 1970, с. 25, 26, 37, 41, 44, 45, 48, 134.

7. Лавдовский М.Д. Наши понятия о живой клеточке и ее происхождении. Изв. ВМА, № 2, 3, 1901, с. 269-284.

8. Лепешинская, Ольга Борисовна. Wikipedia [tiešsaiste]. [Skatīts 2010.22.VII]. Pieejams: http://ru.wikipedia.org, meklēt: Лепешинская, Ольга Борисовна.

9. Вермель Е. История учения о клетке. Москва: Наука, 1970, с. 241-246.

10. Маловичко Е., Рупасова Т. Материалы к вопросу о роли живого вещества в процессе заживления ожогов. Архив АГЭ, 1953, т. 30, № 3, с. 23-27.

11. Jānis Lielmanis dzīvē un darbā. Rīga: Zemkopības ZPI "Agra", 1994, 5.145. lpp.

12. Lielmanis J. Augkopība. 1. izd. Rīga: Lauksaimniecības pārvalde, 1938. 307 lpp.

13. Lielmanis J. Augkopība. 2. izd. Rīga: A. Punkas apgāds, 1944. 295 lpp.

14. Lielmanis J. Augkopība. 3. izd. Rìga: VAPP grāmatu apgāds, 1945. 288 lpp.

15. Bumbieris J. Neatlaidīgi atmaskojot buržuāzisko nacionālistu izlēcienus. Padomju Latvijas Bol̦šsviks, Nr. 8, 1947.IV, 39.-42. lpp.

16. Latvijas PSR ZA pilnsapulces rezolūcija "Par Vissavienības V. I. L,enina v. n. Lauksaimniecības ZA sesijas rezultātiem jautājumā par stāvokli biolog̣ijas zinātnē (arī par J.Lielmaṇa grāmatu "Augkopība"). Cīna, Nr. 218, 1948.1.IX, 2. lpp.

17. Avotiņšs-Pavlovs K. Mācīsim studējošai jaunatnei Mičurina un Lisenko bioloğijas zinātni. Cīna, Nr. 203, 1948.27.VIII, 2. lpp.

18. Zālītis J. Problēmu spriegums.//Jānis Lielmanis dzīvēe un darbā. Rakstu krājums. Rīga: Latvija Valsts Zemkopibas ZPI "Agra",1994, 83.-84. lpp.

19. Latvijas Valsts universitātes vēsture 1940-1990. Rīga: 1999, 375. lpp.

20. I. Heniņa. Matemātikas profesora Arvīda Lūša (1900-1969) pedagoğiskā un zinātniskā darbība.//LU Raksti. 639. sēj. Rìga: 2001, 222.-228.lpp.

21. Latvijas Universitāte divdesmitos gados: 1919-1939. Rīga: 1939, 311.312. lpp.

22. Jānis Lüsis [tiešsaiste]. Latvijas Izglìtïbas informācijas sistēma [skatīts 2010.22. VII]. Pieejams: http://www.liis.lv/biologi/lusis.htm

23. Daija G. G̦enētiķim un zoologam Jānim Lūsim -100.//Dabas un vēstures kalendārs 1997. gadam. Rīga: Zinātne, 1996, 243.-246.lpp.

24. Latvijas Valsts Universitātes vēsture: 1940-1990. Rīga: 1999, 375. lpp.

25. Latvijas Universitātei 75. Rīga: 1994, 124. lpp.

26. Raipulis, J. Jānis Lūsis (1887-1979). Rīga: LPSR Grāmatu draugu biedrība, 1987, 4. lpp. 
27. Latvijas enciklopēdija. 4. sēj. Rīga: Valērija Belokoṇa izdevniecība, 2007, 130., 256. lpp.

28. Pormale M. Profesore Veronika Rozenbaha. Rīga: autores izdevums, [2005]. 64 lpp.

29. Liepiņš M. Sirds siltums. Padomju Medikis, Nr. 13,1969.

30. Dālmane A. Dzeltenuma veidošanās morfoloǵija un histoḳimija vistas ovocìtos. Med. zin. kand. disert. Rìga: 1955. 329 lpp.

31. Dālmane A. Dzeltenuma veidošanās morfoloǵija un histoķimija vistas ovocìtos. Autoreferāts krievu val. Rīga: 1955. 16 lpp.

32. Gerke P. Zur Frage der Dotterbildung im Ovarialei von Amphioxus lanceolatus. Zeitschrift f. mikr.anat. Forschung, 1933, Bd. 34, S. 125-130.

\section{The gloomy repression years of Stalin in the University of Latvia (Summary)}

\section{By Aina Dālmane}

By the middle of the 20th century the represials of Stalin had reached science. This piece takes a look at the first Latvian genetic engineers - the agriculturist Jānis Hilarijs Lielmanis (1895-1970) and the zoologist Jānis Lūsis (1897-1979), who did not decline their scientific beliefs in the time of T. Lisenko and O. Lepešinskas false biology, and therefore had lost their jobs.

Professor V. Rozenbaha (1916-2003), who was persecuted by the KGB after the war, because her husband had been a legionnaire. The University of Latvia Medical department (which later became the Riga Institute of Medicine) hosted an unspoken resistance to false science. Professor K. Bogojavlensky (1899-1967), who worked there, assumed that the foolishness has to battled with undeniable facts. A dissertation, on the morphology and histochemistry of yolk forming in the chicken's ovocit, was prepared under his guidance, which was corresponding to the teachings of O. Lepešinska. The work proved that there is no DNA in yolk, and therefore emergence of cells from the spheres of yolk is not possible.

Aina Dālmane, profesore, Dr. med. habil. emeritus

LU Medicīnas fakultāte 